\title{
Review on Euphorbia neriifolia Plant
}

\author{
Bapu R Thorat* and Vikky Bolli \\ Department of Chemistry, Ismail Yusuf Arts, Science and Commerce College, India
}

Received: November 03, 2017; Published: November 13, 2017

*Corresponding author: Bapu R Thorat, Department of Chemistry, Government of Maharashtra, Ismail Yusuf Arts, Science and Commerce College, Jogeshwari (East), Mumbai (M.S.) India, Tel: 9892786625; Email: iycbrthorat@gmail.com

\begin{abstract}
The present review is an attempt to highlight of Euphorbia neriifolia - Indian ethno-medicinal plant which was to be scientifically proved with different pharmacological activities such as laxative, carminative, bronchitis, tumors, leucoderma, piles, inflammation, enlargement of spleen, anemia, ulcers, fever and for wound healing along with some harmful effect to human being especially latex of plant.
\end{abstract}

Keywords: Euphorbia neriifolia; Herbal drugs; Medicinal plants; Wound management, Latex

\section{Introduction}

Medicinal plant usage is as old as humankind in the therapeutics. There are about 45,000 medicinal plants species in India. The officially documented plants with medicinal potential are 3000 but traditional practitioners use more than 6000 . Bioactive compounds in plants have also been utilized for additional purposes, namely as arrow and dart poisons for hunting (several Aconitum species), poisons for murder, hallucinogens used for ritualistic purposes, stimulants for endurance, and hunger suppression, as well as inebriants and medicines. The plant chemicals (bioactive compounds) used for pharmacological or toxicological effects are largely the secondary metabolites. These secondary metabolites called bioactive compounds can be classified into several groups according to their chemical classes, such alkaloids, terpenoids, cardiac glycosides, saponins, steroids, limonoid, tannins, flavonoids, and phenolics [1]. In $18^{\text {th }}$ century and before that, the plants are major source for the treatment of different diseases and infections.

Now a day's some of the plant derived natural products that includes vinblastine, vincristine, taxol, podophyllotoxin, camptothecin, digitoxigenin, gitoxigenin, digoxigenin, tubocurarine, morphine, codeine, aspirin, atropine, pilocarpine, capscicine, allicin, curcumin, artemesinin and ephedrine among others are also used as drug in pure form or in crude form or mixture. Some of them are synthesized synthetically but about 121 (45 tropical and 76 subtropical) major plant drugs have been identified for which no synthetic route is currently available (Figure 1).

Figure 1

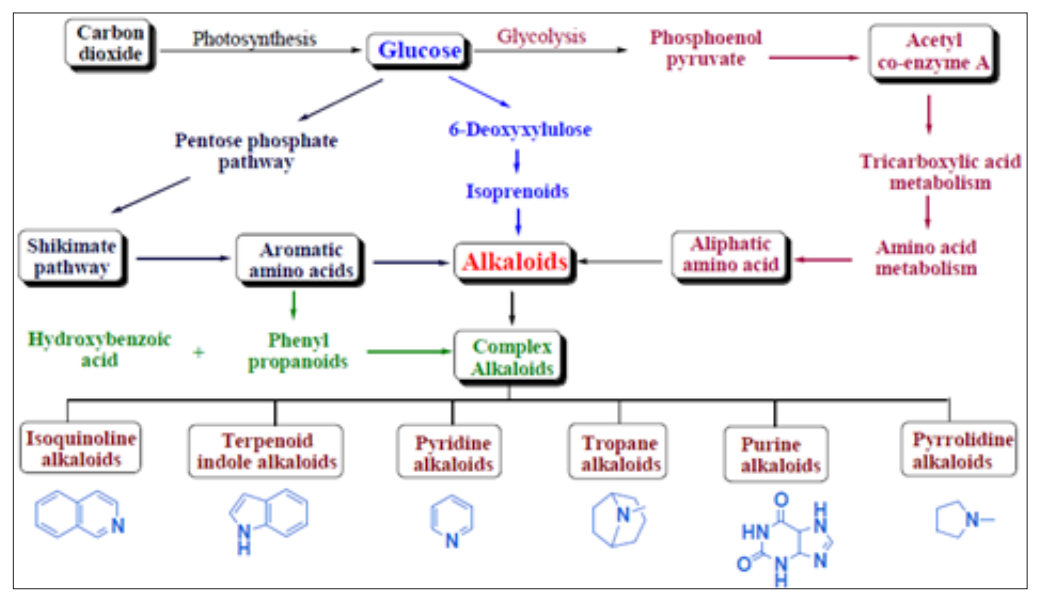


According to the World Health Organization (WHO) till 2003 about $80 \%$ of the population of developing countries are unable to afford pharmaceutical drugs, so they goes to plant based medicines to sustain their primary health care needs [2]. 252 drugs are considered as basic and essential by the WHO and out of those $11 \%$ are exclusively of plant origin and a significant number are synthetic drugs obtained from natural precursors. India has an official recorded list of more than 45,000 plants species and estimated list of more than 7,500 species of medicinal plants growing in its 16 agroclimatic zones under nearly 63.7 million hectares of forest courage [3].

Euphorbiaceae, the spurge family, comprises five subfamily, 49 tribes, some 7300 species and 283 genera of flowering plants distributed primarily in the tropical regions $[4,5]$. The largest genus of family Euphorbiaceae is Euphorbia with about 1600 species. They range from annual weeds, vines, succulents, herbs (Phyllanthus amarus), shrubs (Ricinus communis) and trees (Phyllanthus emblica). In several species of Euphorbia, the stem is modified to perform photosynthesis. There are more than 35 species are found in tropical, subtropical and warm temperate regions of South-East Asia; Vietnam has more than 24 species, Thailand has 25 , Sumatra has 6, Java has 5, Borneo has 5, Philippines has 6, Sulawesi has 5 , Lesser Sunda Islands has 11, Moluccas has 7 and New Guinea 15, Australia has 45 species [6]. In our country, the family is represented by several genera such as Euphorbia, Ricinus, Phyllanthus, Croton, Pedilanthus, etc. It is characterized by the presence of white milky latex that exudes when broken and which is more or less toxic, and some are useful as a source of oil or wax. The flowers are always unisexual. The leaves are stipulate or exstipulate, petiolate, alternate (e.g. Ricinus communis), simple, entire or deeply lobed or trifoliately compound (e.g. Hevea brasiliensis) and with unicostate or multicostate reticulate venation. In xerophytic species of Euphorbia, leaves are reduced or absent.

The Euphorbia is named after a Greek surgeon called Euphorbus. He was physician of Juba II who was the Romanised king of a North African kingdom, and is supposed to have used their milky latex as an ingredient for his potions. The latex of these species has different medicinal application along with some poisonous effect. Euphorbia neriifolia Linn (Indian Spurge tree, Hedge Euphorbia commonly known as Snuhi) belong to the family Euphorbiaceae, is one of the different species of Euphorbia genus plants, with wide range of local medicinal uses throughout the areas in which it is grown. This is one of the herbs extensively used in the Indian system of medicine. They all have latex and a unique flower structure. Euphorbia neriifolia plant is reported to contain sugar, tannins, flavonoids, alkaloids, 24-methylene cycloartenol, triterpennoidal saponins, etc. As Euphorbia neriifolia plant is selected for the review because of wide variety applications in the traditional medicines such as for the treatment of abdominal troubles, bronchitis, tumors, leucoderma, piles, inflammation, enlargement of spleen, anemia, ulcers, fever and in chronic respiratory trobles [7]. It used as analgesic, hepatoprotective, immunostimulant, anti-inflammatory, mild CNS depressant, wound healing, redioprotective agent [7]. A significant percentage is succulent, but they are mostly originating from Africa and Madagascar.

\section{Different Names of The Plant}

a) Hindi name - Sehund, Danda thukar [8].

b) English name - Common milk hedge, Holy Milk Hedge, Dog's Tongue

c) Arabic name - Jakum

d) Kannada name - Male kalli

e) Marathi name - Thor, Tridhara Nivdunga

f) Malayalam name - Illa kalli

g) Punjabi name - Thor

h) Telugu name - Akujemuddu

i) Tamil name - Ilaikalli

j) Sanskrit - Snuhi

k) Latin - Euphorbia Neriifolia

l) Ayurveda - Sthavara visha varga, Upavisha

\section{Plant Profile}

a. Botanical name: Euphorbia neriifolia

b. Family: Euphorbiaceae

\section{Scientific Classification}

A. Kingdom: Plantae

B. Subkingdom: Tracheobionta (Vascular plants)

C. Superdivision: Spermatophyta (Seed plants)

D. Division: Magnoliophyta (Flowering plants)

E. Subfamily: Euphorbioideae

F. Tribe: Euphorbieae

G. Class: Magnoliopsida (Dicotyledons)

H. Subclass: Rosidae

I. Order: Malpighiales (Figure 2)

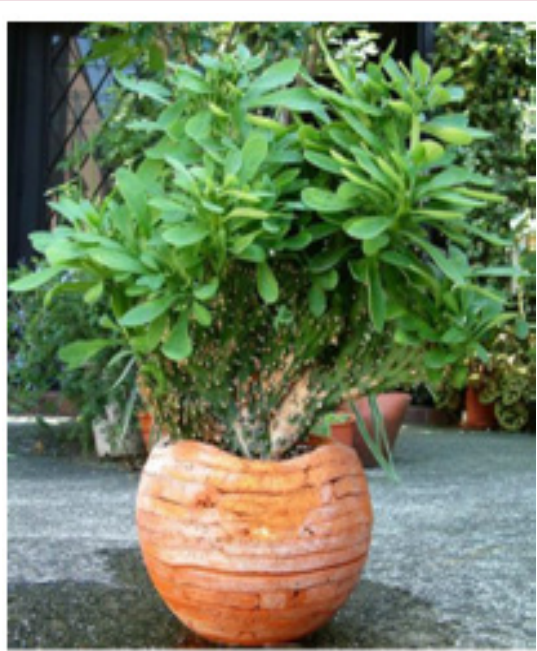

Figure 2: Genus: Euphorbia 


\section{Species [9]:}
a) E. nerifolia linn - Patra Snuhi
b) E. nivulia Buch - Ham
c) E. antiquorum Linn - Tridhara Sehunda
d) E. trigona Haw - Tridhara Sehunda bheda
e) E. royleana Boiss - Thuhara
f) E. Tirucalli - Kanda snuhi

\section{Distribution}

Euphorbia neriifolia grows widely around the dry, rocky and hilly areas of north, central and South India mostly in Deccan Peninsula and Orissa. It is indigenous plant of South Asia, but now locally cultivated and naturalizing in Sri Lanka, India, Burma (Myanmar), Bangladesh, Thailand and throughout the Malaysian region except for Borneo; also occasionally cultivated in other topical regions. It is also found in E. Asia - S. China, Vietnam, and New Guinea [6]. Euphorbia is an herb and deciduous. The parts of the plant that grow above the ground are used to make medicine.

\section{Morphological Description}

Euphorbia neriifolia is cultivated in gardens, and is apparently spontaneous. Small erect fleshy glabrous shrub, erect, branches $3 / 4$ in diameter jointed cylindric or obscurely 5-angled with sharp stipular thorns arising from thick subconfluent tubercles in 5 irregular rows like cactus. The branches are 2-4 meters high, the trunk and older branches are grayish and cylindrical; medium branches are being slightly twisted, stoud, freshy, and 4 or 5 angled or winged; younger ones are usually 3-winged, wings labulate with a pair of stout, sharp, 2- to 4- $\mathrm{mm}$ long spines rising from the thickened bases at each leaf of petioles-scar [7]. Leaves are succulent, deciduous, 6-12 inch long, terminal on the branches, waved narrowed into a very short petiole. The leaves are arise from the sides of wings towards the end of the branches, are fleshy, oblong-obviate, $5-15 \mathrm{~cm}$ long, or in young plants somewhat longer, painted or blunt at the tip [7]. This plant is leafless for most part of the year, except during monsoon when fresh leaves appear.

Inflorescence or the arrangement of flowers in a bunch on the plant is "cyathium" type, means one female and several male flowers are found on a same bunch. Female flowers consist of a trichambered ovary, which usually elongates in fruits. Male flowers many, bracts linear. Female flowers rarely developed. Each chamber contains an ovum. Involucres are yellowish 3-nate, the lateral ones of the cymes shortly thickly pedicelled, central sessile; lobes large, erect, roundish, cordate, fimbriate; glands transversely oblong; bracteoles most abundant, fimbriate. Fruits are three chambered, tricoccaus, but so deeply divided that it has the appearance of 3 radiating slender follicles.

\section{Botanical Description [10]}

Euphorbia neriifolia, is a bitter, xerophytic, prickly, succulent shrubby, fleshy, large, erect much branched shrub, which sometimes grows into a small tree of 2-8 meters height or more with rounded branches cactus like plant. The tree looks somewhat like a cactus but with large, persistent leaves on younger parts of the plant, and growing up to 8 meters $[4,11]$.

Stem: Green and cylindrical stem and large branches also being round and terete, spiral ridge portion, Sharp stipular thorns, with hollow space in centre containing white reticulate mass. The younger branchlets are somewhat verticillate, with two or more whorls without articulations, fleshy, cactus-like, swirled, light-green, glabrous, 8-30 (-40) mm thick, often leafless, and spine shield in 5 distinct rows on more or less distinct angles (not winged) which are visible for a long time [12]. The trunk and older branches are being grayish and cylinder. Bunches of succulent thick leaves occurs on the branches [4]. Central meristem is prominent throughout plastochronic phases. There is close histogenic relationship between central and peripheral meristem [13]. The leaves arise from the sides of wings towards the end of the branches.

Leaves: The fresh young leaves are simple, dark green in colour having leathery texture. The surface is glabrous with reticulate venation. The average leaf size is $(8-14 \pm 2) \mathrm{cm}$ (length) and (4$8 \pm 2) \mathrm{cm}$ (breadth) and $(1.3 \pm 0.2) \mathrm{mm}$ (thickness) with pointed and acute tip [14]. Peri-clinical divisions in the third and fourth layers of peripheral meristem initiate the leaf [4]. During vegetation period they are deciduous but in the late summer they fall.

Stippular thorns: The spines are short, about 4-12 mm long arising from the ribs, grayish brown to black in color, sharp, persistent, from low conical truncate distant, spirally arranged tubercles 2-5 mm height and 2-3 cm apart [4,12].

Flowers (terminal, corymbose): Both male and female flowers are found in the same bunches of the herb. Flowers when viewed as a whole, looks like a single flower. 3 to 7 flowered cymes or panicles appearing laterally in the axils of the upper leaves on short, rigid and forked peduncles, Flattened-globose, 1.5-2 mm x 4-5 mm, reddish, prominent in groups of tree, the central one is subsessile, the lateral ones with apeduncle of 6-7 mm, cyathial glands 5 oblong, 1-3 mm broad. Corolla absent but the involucres has two nearly round to ovate, bright red bracts 3-7 mm long. Inflorescence or the arrangement of flowers in a bunch on the plant is cyathium type (one female and several male flowers are found on a same bunch) [12]. Basically, male flowers many, bracts linear while female flowers rarely developed. Flowers and fruits occurs during the month of December to May [4].

Fruits: Fruits (capsules) are three chambered or 3-lobed, smooth, stigmas slightly dilated and minutely toothed with 10-12 $\mathrm{mm}$ in diameter [4].

Latex: Latex is a milky-sap-like fluid found in cells or vessels and usually executed after tissue injuries that make up the laticiferous system [13].

Cultivation Needs: Needs full exposure to the sun but can also succeed to grow in light shade. They prefer rocky areas for the growth. They need well drained soil. Grows well in dry place and rocky area in villages of all over India [15-17]. It needs no maintenance. It is a moderately fast grower, and will quickly become large landscape masterpieces in just 3-5 years. Water regularly during the active growing season (at least weekly) from March to 
September but no water should ever be allowed to stand around the roots. Keep almost completely dry in winter.

\section{Chemical Constituents}

Phytochemical investigations on Euphorbia neriifolia yielded in the isolation of several classes of secondary metabolites, many of which expressed biological activities such as Euphol $(8,24$ euphadien-3 $\beta$-ol), monohydroxy triterpenes, nerifoliol, taraxerol, flavonoids, steroidal saponins, sugar, tannins, alkaloids, $\beta$-amyrion, glut-5(10)-en-1-one, cycloartenol, 9,9-cylolanost-20(21)ene-24-ol- 3-one (neriifolione), and triterpenoidal saponin [18,19]. Chemical constituent present in different part of plant: Euphol (Whole plant, bark, latex, root); friedelan-3区 and $3 \beta$-ol, D:B-friedoolen5(10)-en-1-one, glut-5(10)-en-1-one and taraxerol (stem, leaves); n-hexacosanol, euphorbol, hexacosanoate, 12-deoxy-4 $\beta$ hydroxyphorbol-13-dode-canoate-20-acetate and pelargonidin3,5-diglucoside (bark); 24-methylenecycloartenol and tulipanindiglucoside (bark, root); nerifoliol (latex), cycloartenol, euphorbol, ingenol triacetate, 12-deoxyphorbol-13,20-diacetate, delphinidin3,5-diglucoside (root) [19-21] (Figures $3 \& 4$ ).

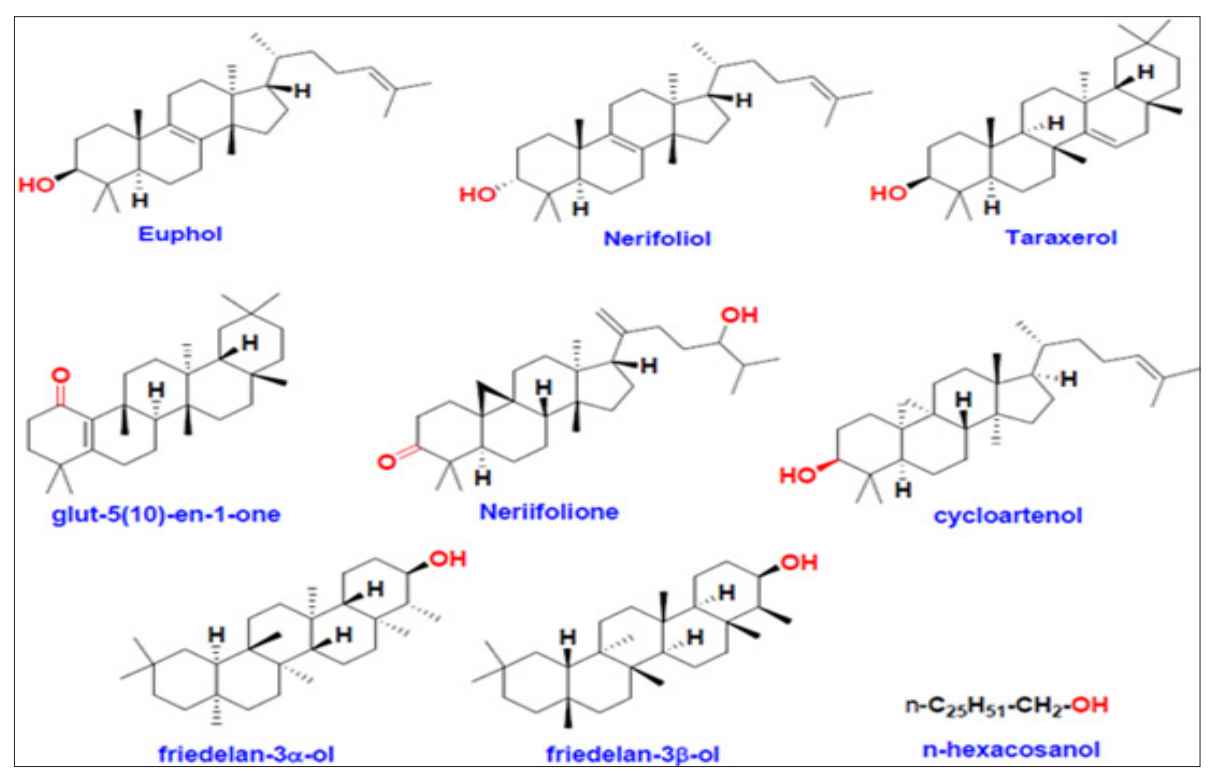

Figure 3

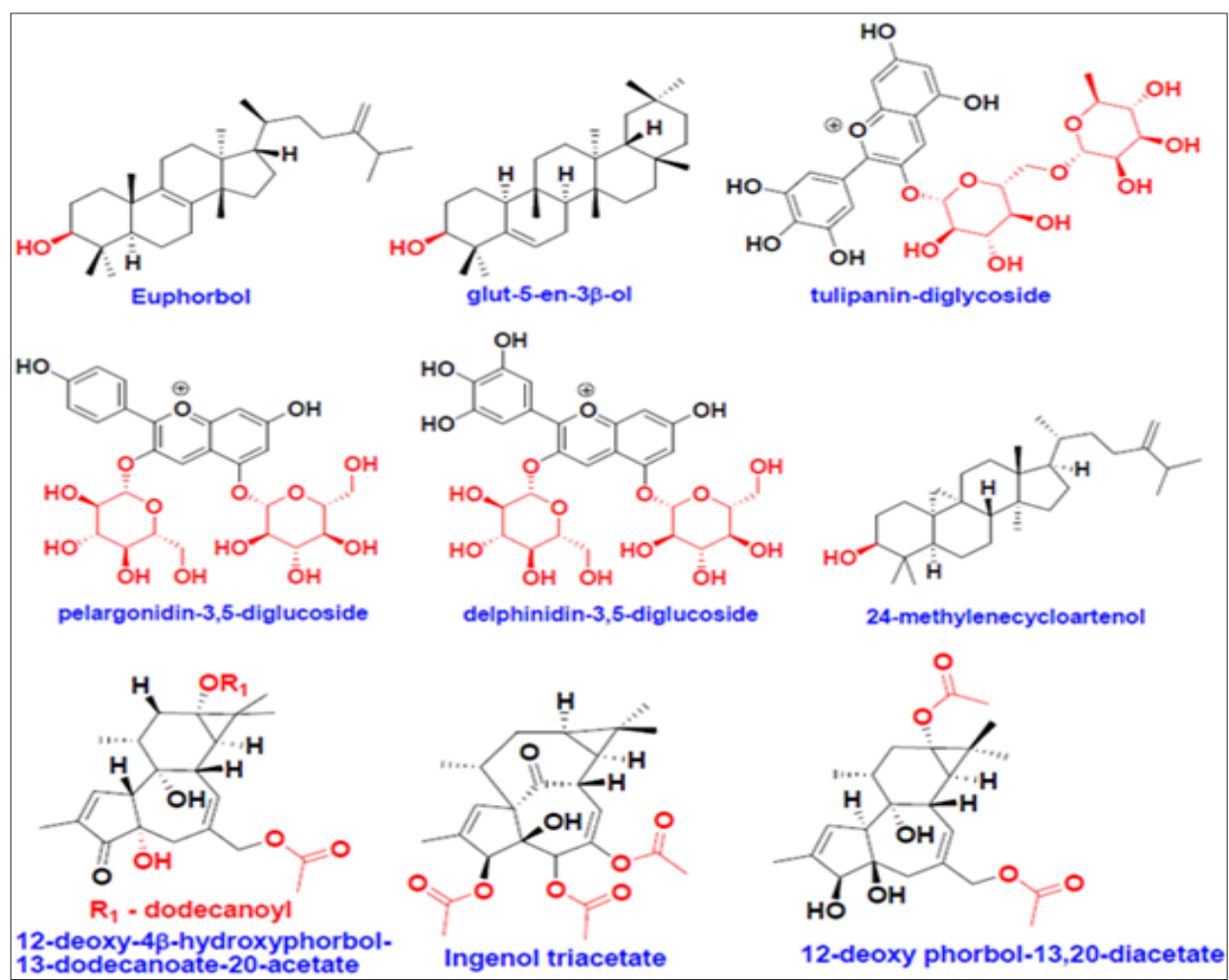

Figure 4 
Latex portion contain 69 - 93.3\% water and water soluble and $0.2-2.6 \%$ caoutchouc $[22,23]$. The latex of E. neriifolia is an active ingredient of many Ayurvedic formulations like Abhaya lavana, Avittoladi bhasma, Citrakadi taila, Jatyadi varti, Snuhidugdhadi varti, Snuhi ghrta and Jalodarari ras. It (gum resin) was found to contain Euphol, neriifoliol, neriifolene, Euphorbon, Resin, gum, caoutchouc, malate of calcium, monohydroxy triterpene, taraxerol, $\beta$-amyrion, glut- 5-(10)-en-1-one, neriifolione and cycloartenol [24].

Fresh latex yields $10.95 \%$ solid with $18.32 \%$ total resinous matter, and $24.50 \%$ and $16.23 \%$ of total diterpene and triterpene respectively. A gum resin which is the active principle, traces of an alkaloid; wax, caoutchouc, chlorophyll, resin (2.40\%), tannin, sugar, mucilage, calcium oxalate, carbohydrates albuminoids, "gallic acid quercetin, a new phenolic substance and traces of an essential oil". Neriifolin-S and neriifolin, 9,19-cyclolanost-22(22'),24-diene-

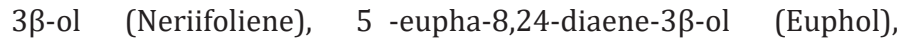
Neriifoliene and euphol, 9,19-cyclolanost-20 (21)-en-24-ol-3-one (Neriifolione), cycloartenol, Neriifoliol, Lectin, etc are the chemical constituents extracted from fresh [25-29] or dried latex [30,31] of E. neriifolia. The leaves of Euphorbia neriifolia $L$. were found to be highly fibrous (nearly 15.36\%). It may contain suberin or cutin, some amount of carbohydrates, cellulose and lignin. It contains higher amount of calcium oxalate crystals and starch than stem and leaves. It contain high values of total ash, and smaller values of acid insoluble and water soluble ashes. The leaves of Euphorbia neriifolia L. were found to be rich in calcium and potassium [32]. The results of phytochemical screenings of hydro-ethanolic, petroleum ether, benzene, chloroform, ethyl acetate, ethanol and aqueous extracts of leaves mainly revealed the presence of proteins, glycosides, alkaloids, phenolics, flavonoids, saponins and terpenoids in appreciable, moderate and trace amount. The proteins and amino acids were possessed in negligible amount [14].

In one of the study, the hydroalcoholic extract of $E$. neriifolia was found to contain sugar, tannins, flavonoids, alkaloids, 24-methylene cycloartenol, and triterpennoidal saponins on preliminary phytochemical analysis and there is absence of fixed oils and glycosides. Several triterpenoids like Glut-5-en-3 $\beta$-ol, Glut-5(10)-en-1-one, taraxerol and $\beta$-amyrin have been isolated from the powdered plant, stem and leaves of E. neriifolia. The leaf extracts in the water and organic solvents such as chloroform, ethanol, ethyl acetate, and butanol of E. neriifolia were found phlobotannins, flavonoids, saponins, tannins, terpenoids, phenols and cardenoloids [33,34].

a) Moisture content: Leaf $73.8 \%$, Stem $62.4 \%$, Bark $86.9 \%$ Whole plant 78.6 [35].

b) Oil content: Leaf 2.46\%, Stem: 3.56\%, Bark 4.95\%, Whole plant $3.87 \%$ [35].

c) Polyphenol content: leaf 4.67\%, Stem 9.63\% Bark 12.68\% Whole plant $11.49 \%$ [35].

d) Hydrocarbon content: leaf $0.42 \%$, Stem $2.58 \%$, Bark 2.93 , Whole plant $2.28 \%$ [35].

\section{Pharmacological Uses}

Plants are bitter, laxative, carminative, acrid, pungent, improves appetite, abortifacient, digestive, expectorant, depurative, febrifuge, stomachic, vermifuge, useful in abdominal troubles, bronchitis, tumors, loss of consciousness, asthma, leucoderma, piles, inflammation, enlargement of spleen, anemia, ulcers, cutaneous diseases, dropsy, dyspepsia, pain, flatulence intermittent fever, fever and in chronic respiratory troubles [36-38].

a. The leaves are diuretic. The leaves are heated, squeezed, and the sap taken, sometimes with salt, to treat asthma, wheezing in babies, colds, aphrodisiac, and stomach upset. The leaves are also used to treat fevers, coughs and colds, carminative, stomachic and expectorant, chronic respiratory troubles, bleeding piles and diabetes [34,39,40]. Applied externally, the sap is used to treat infected nails and to relieve earaches. The expressed juice of the leaves is reported as very effectual in relieving the paroxyms of spasmodic asthma. The anti-inflammatory and analgesic activity of hydro alcoholic leaves extract of Euphorbia neriifolia is due to the presence of flavonoids [41].

b. In a study, E. neriifolia leaf extract was found to be a potent analgesic, anti-inflammatory, mild CNS depressant, wound healing activity along with humoral and cell mediated immunostimulating activity [42]. E. neriifolia reduced serum lipid profile and glucose signifying catabolic property with added in vivo and in vitro antioxidant activity.

c. The bark has been used as a strong purgative. The root is considered antiseptic, antispasmodic, purgative and local rubefacient activity [34]. Mixed with black pepper, it is employed in the treatment of snake bites both internally and externally.

d. The latex also reported its oral efficacy and safety on adjuvant arthritis, skin warts, and earache [37]. In a 14-day repeated dose sub-acute toxicity study, the drug showed to possess striking anti-arthritic activity. The white, acrid, milky juice (latex) is internally a purgative and externally it has rubefacient properties. As drastic purgative, it is given in combination with other medicines such as chebulic myrobalan, longpepper, trivrit root and which are kept steeped in it in cases of ascites, anasarca and tympanitis. The latex juice is also applied to remove warts and similar excrescences and to afford relief in earache; mixed with shoot it is used as an anjan in ophthalmia; mixed with margosa oil it is used as an application in rheumatic affections. The juice is largely used with clarified or fresh butter as an application to unhealthy ulcer and scabies and applied to glandular swellings to prevent and suppuration. It is expectorant, pungent and is thus used in treating tumors, arthritis and abdominal pains. Turmeric powder mixed with the milky juice of Euphorbia neriifolia is recommended to be applied to piles. The tribal population of Chattishgarh region uses the milky latex as an ingredient of aphrodisiac mixture $[37,43]$. 
e. $\quad 0.5 \%$ and $1 \%$ sterile water soluble fraction of E. neriifolia latex was evaluated for wound healing activity in guinea pig. $E$. neriifolia latex showed increase in collagen and DNA content improving the tensile strength. It also showed increased epithelization and angiogenesis indicating potential wound healing property $[7,44]$. There is report of its anti-inflammatory and antiarthritic activity of a novel triterpene (Nerifolione) isolated from the latex of E. neriifolia along with total extract of latex in acetone.

f. Antibacterial effect was found of the leaf extract of E.neriifolia in the ethanol and chloroform when was tested against the different bacterial organisms and it was believed to be due to the presence of tannins, phlobatannins, saponin, cadenoids, phenol, terpenoids and flavonoids which have been shown to possess antibacterial properties. The water and ethyl acetate extract exhibited very less activity [31].

g. Analgesic and Anti-inflammatory study had been carried out of the $70 \%$ hydroalcoholicleaves extract of E.neiifolia by using tail flick method and the Carrageen induced hind paw edema method, which had led to the confirmation of the analgesic and anti-inflammatory activity of E.neriifolia. The analgesic effect of leaf hydroalcoholic extract was also evaluated using Eddy's hot plate method in albino rats. It shows significant analgesic and Anti-inflammatory activity as compared to the standard drugs, diclofenac sodium and indomethacin respectively $[7,45]$. The anti-inflammatory activity of petroleum ether fraction of latex of E.neriifolia is also studied on the rat by paw edema method. The pet. Ether fraction contains triterpenes euphol, nerifoliol and cycloartenol having anti-inflammatory and analgesic activity $[7,46]$.

h. E. neriifolia leaf extract was found to be mild depressant on central nervous system at higher doses. E. neriifolia leaf extract at $400 \mathrm{mg} / \mathrm{kg}$ dose potentiates pentobarbitoneinduced duration of sleep. Leaf extract did not have any motor in coordination or ataxia on muscle grip performance in mice effect in rota rod test and showed statistically insignificant reduction in locomotor activity. The elevated plus-maze introduced by Lister for mice is based on the apparent natural aversion of rodent to open and high spaces which forms the basis for its use in the measurement of anxiety as well as short-term memory. E. neriifolia at $400 \mathrm{mg} / \mathrm{kg}$ dose exhibited pronounced antianxiety activity by significantly increasing preference to open arm percent number of open arm entries and percent time spent in open arm. The results of the present study showed that the mice spent a significantly higher time in the open arm and also entered them more frequently signifying the anti-anxiety activity.

i. The E. neriifolia leaves extract and isolated flavanoid significantly restored the antioxidant enzyme level in the kidney and exhibited significant dose dependent protective effect against DENA induced nephrotoxicity, which can be mainly attributed to the antioxidant property of the extract. This study paid way for the use of hydroethanolic extract of E. neriifolia as anti-carcinogenic potential and for protection of ENF against DENA induced renal cancer [47]. DENA exposed animals showed alterations in normal hepatic histo-architecture, which comprised of necrosis (N), dilated sinusoids and vacuolization of the cells. Mice treated with E. neriifolia lower (ENL) and higher (ENH) dose and ENF before intoxicated with DENA showed that the liver cells were normal, with very little necrosis. The ENH and ENF protect the hepatic tissue against DENA-induced hepatic carcinoma [48].

j. The extract of E. neriifolia leaves possesses antioxidant properties and could serve as free radical inhibitors or scavengers, acting possibly as primary antioxidants. The antioxidant activity of ethanolic extract of $E$. neriifolia was evaluated by various antioxidant assays such as TAC, FRAP, FTC, TBA and non specific activity. All the result of anti oxidant activities found were compared with standard antioxidants. The highest antioxidant property was found for the ethanolic leaf extract of E. neriifolia [7,49]. The catabolic and antioxidant effect of the extract may be due to presence of saponins and flavanoids [50].

k. The hydro-alcoholic extract of dried leaves of Euphorbia neriifolia possessing significant protection against E.coli induced abdominal sepsis, significant increase in total leucocyte count, differential leucocyte count and phygocytic index were determined. It shows significant activity [51].

1. Different doses of aqueous extract E. neriifolia were administrated to both sex of Wister albino rats along with standard frusemide. The collected urine sample were tested for concentration of $\mathrm{Na}+$ and $\mathrm{K}+$ by flame photometer, the tested samples increases the urine volume as an effective hypermatraemic and hypercholaemic diuretic [7,52].

m. The anti-diabetic and anti-hyperlipidemic activity of ethanolic extract of leaves of E. neriifolia was studied on the type-2 diabetic rats. After 21 days of oral administration of 200 - $400 \mathrm{mg}$ per kg of etanolic extract produced decrease on fasting blood glucose, triglyceride, cholesterol, LDL levels in HFD-STZ induced type- 2 diabetic rats, on the other hand there was significant increase in HDL levels. It indicates that the ethanolic extract exhibits anti-diabetic potential along with potent lipid lowering effect after repeated oral administration [53].

n. Psychopharmacological profile of hydroalcoholic extracts of E. neriifolia leaves in mice and rats was studied and the result suggested that the leaf extract significantly reduces apomorphine induced stereotypyin mice at all doses. The result also suggested that, the leaf extract shows antipsychotic, anti antianxiety, anti-convulsant activity in mice and rats $[7,54]$.

o. The hepatoprotective effect of saponin fraction of isolated from the leaf extract of E. neriifolia was studied on CCl4-induced hepatotoxicity on rat. During the study they found that cytosolic enzymes like SGPT, SGOT and ALP elevates in the blood and hepatic glutathione and SOD decreases [55]. 


\section{Traditional Uses of $E$. neriifolia [34]}

The plant has been used in Ayurveda, Unani and Sidha. A traditional uses of E. neriifolia (Sehund) as per Ayurveda are - to improve digestion strength (deepana); induces server purgation (rechana); useful in treating disorders of veta-dosha imbalance such as neuralgia, paralysis, constipation, bloating, etc; unctuous oily (snigdha); light to digest (leghu); etc [56].

a. The leaf of E. neriifolia is heated and tied over the area affected with pain and inflammation.

b. The fresh juice from the leaf is poured inside the ears to treat earache, to defrost skin warts, and in arthritis. The milk latex of Euphorbia neriifolia is applied over warts as part of treatment.

c. Oil processed from the leaf of E. neriifolia and sesame oil is used for external application to treat joint pain.

d. The paste of the leaf of E. neriifolia is applied over the skin to treat skin diseases.

e. The vaidhyas from ancient times used to use the milky juice exuded from the injured stems as drastic cathartic and to relieve earache. They are used as a drastic purgative in the enlargement of liver and spleen, syphilis, dropsy, general anasarca, leprosy, etc. It has been found beneficial for Asthma $[6,34]$. The method as found by a Ayurvedic doctor is by the prepared succus consisting of equal parts of the juice of this plant and simple syrup; administered in doses of 10 - 20 drops three times a day; has been found to relieve asthma attacks completely.

f. Latex is acrid, laxative, pungent and good for tumours, abdominal troubles and leucoderma. It is also used as a purgative, rubefacient, carminative, expectorant, whooping cough, gonorrhoea, dropsy, leprosy, asthma, dyspepsia, jaundice, enlargement of the spleen, colic and stone in the bladder. It is use to remove cutaneous eruptions and warts. It is liable to cause dermatitis $[4,15]$. The dried juice with some other ingredients used as a drastic purgative in the enlargement of liver and spleen, syphilis, dropsy, general anasarca, leprosy, etc. Juice is largely used with clarified or fresh butter as an application to unhealthy ulcers and scabies i.e. it is used for cleansing the abdomen in cases of poisoning and in severe constipation. When applied to glandular swellings it prevents suppuration. Mixed with Margosa oil it is applied to rheumatic limbs. The fresh milk latex of Euphorbia neriifolia is used in the preparation of 'Kshara sutra', applied for the medicated thread useful to treat piles and fistula or over external pile mass to reduce it. Turmeric powder mixed with the juice of Euphorbia neriifolia is recommended to be applied on piles. Thread steeped in the above mentioned mixture is used in ligaturing external Haemorrhoids [6,34]. Normally, as found by the survey, Asthma patients take the latex by mixing it with honey. Juice mixed with ghee is given in syphilis, in visceral obstructions and in spleen and liver enlargements due to long continued intermittent fevers. Externally the juice is applied to remove warts. g. Root- bark boiled in rice-water and arrack is given in dropsy [6,34,57]. Root and stem is used as symptomatic treatment of snake bite, scorpion sting and as a antispasmodic. Root and milky juice mixed with black-pepper is employed in scorpion- stings and snake bites, both internally and externally but large dose causes irradiation and determatitis. The stem is roasted in ashes and the expressed juice with honey and borax is given in small doses to promote expectoration of phlegm and juice from fresh stem of E. neriifolia is added with honey and borax to treat cough and sore throat. Pulp of the stem mixed with fresh ginger is used to prevent hydrophobia [57].

h. Euphorbia is used for breathing disorders including asthma, bronchitis, and chest congestion. It is also used for mucus in the nose and throat, throat spasms, hay fever, piles, and tumors. Some people use it to cause vomiting. In India, it is also used for treating worms, severe diarrhea (dysentery), gonorrhea, and digestive problems [4].

i. The tribal population of Chhattisgarh region uses the milky latex as an ingredient of aphrodisiac mixture [7]. The juice of the plant is used in Gujarat for smearing cuts made by tapers on Borassus flabellifer (Linn) in order to prevent the palm from the attack of red weevil. Stem or leaf juice is used in case of cough and cold mixed with honey [58].

j. E. neriifolia latex is one of the constituents of "Kshaarasootra", which is used in Indian medicine to heal analfistula. A multicentric randomized controlled trial carried out by Indian Council of Medical Research revealed that the long term out come with "Kshaarasootra" was better than with the surgery offering an effective, ambulatory and safe treatment for patients with fistula-in-ano [59].

k. Euphorbia neriifolia Plant used in different Ayurvedic medicines, some of them are listed here - Agnivrana Taila (for burns, boils, etc), Ayaskirti (for anemia, weight loss therapy, skin diseases, etc), Vishatinduka taila (for gout, numbness, skin diseases), Abhaya lavana (for liver and spleen disorder), Madhusnuhi rasayana (for skin diseases like eczema, psoriasis, diabetics, carbuncles, piles, tumors, goiter, iching, rheumatoid arthritis, etc), Shanka dravaka (for ascites, indigestion, liver and spleen diseases), etc.

\section{Harmful Effects}

\section{The latex portion of the plant is actually regarded as the toxic part in the plant [10].}

a. The plant is poisonous and skin contact with the sap can cause blistering: The milky latex or sap of Euphorbia species is found to be toxic and may cause intense inflammation of the skin and the eye. Ocular toxic reaction ranges from mild conjunctivitis to severe kerato-uveitis. Corneal involvement generally follows a typical sequence with worsening of edema with epithelial sloughing on the second day. It is believed that some species are more toxic than the others. Few cases have also been reported about the permanent blindness occurring due to the accidental inoculation of the Euphorbia neriifolia 
latex. When treated early and managed meticulously, the inflammation generally resolves without sequelae [60].

b. The leaves and roots is used as a fish poison [60].

c. The injection of the latex causes Irritation, Vomiting, Diarrhoea, Burning sensation in the abdomen, Convulsions and Coma. On contact with the skin there will be Burning of skin and vesication [61].

d. There will be Inflammation of eye and temporally Blindness if the milk of plant falls to the eye. Treatment for the person who has been come in contact with the latex can be washing the contact part with running water. It holds good even for the contact with the eyes [54].

\section{The symptomatic treatment includes [12]:}

a. On ingestion: Gastric lavage is recommended with normal saline or Activated charcoal.

b. On contact: with the skin - Topical corticosteroids are used, with Eye- Antibiotic eye drops, Tears substitute, IOP (Intra ocular pressure) lowering medications.

The post mortem investigation showed the Signs of inflammation of contact part, gangrenous patches in the stomach and rotten spleen. The medico-legal importance includes accidental poisoning, Homicidal and suicidal purposes, which are very rare and used for procuring criminal abortions [12].

\section{Conclusion}

Utilization of plants for medicinal purposes in India has been documented long back in ancient literature because they are essential for human survival. Traditional medicinal system is widely distributed in India. A major proportion of population mostly belonging to rural areas is still dependent on traditional system of medicines for their various health needs. Therefore, traditional and cultural medical knowledge has a catalyzing effect in meeting health care demands. From the available literature survey, it should clearly show that Euphorbia neriifolia L. serve as an important source of many therapeutic efficient chemicals. It is extensively used in an Indian medicine system in combination with other plants and natural products. This plant is useful in abdominal troubles, bronchitis, tumors, loss of consciousness, asthma, leucoderma, piles, inflammation, enlargement of spleen, anemia, ulcers, cutaneous diseases, dropsy, dyspepsia, pain, flatulence intermittent fever, fever and in chronic respiratory troubles due to present of different natural products as Euphol, monohydroxy triterpenes, nerifoliol, taraxerol, flavonoids, steroidal saponins, sugar, tannins, alkaloids, $\beta$-amyrion, proteins, glycosides, alkaloids, phenolics in appreciable, moderate and trace amount. This is one plant has been successfully used in many health problem since a long period of time for the treatment of wide variety of health issues. There is scope for developing newer drug molecule or mixture for the treatment of multiple diseases only by changing the dosage. The Euphorbia neriifolia $L$. is poisonous and skin contact with the sap can causes blistering.

\section{References}

1. Harborne J B (1984) Phytochemical Methods: A Guide to Modern Techniques of Plant Analysis ( $2^{\text {nd }}$ edn) Chapman and Hall, New York, USA.

2. Padma T V (2005) India Ayurveda Nature pp. 436-486.

3. Tag H, Das A K, Loyi H (2007) Natural Product Radiance 6(4): 334-340.

4. Kirtikar KR, Basu BD (2006) Indian medicinal plants. ( $2^{\text {nd }}$ edn) Allahabad, India, Lalit Mohan Basu pp. 3: 2201-2204.

5. Webster GL (1994) Classification of the Euphorbiaceae. Ann Mo Bot Gard 81(1): 03-32.

6. Medicinal and poisonous plants. Plant resources of South- East Asia No. 12(1): 1

7. Shaikh A Ahmed, Sayyed Nazim, Shaikh Siraj, Patel M Saddik, Chavda Ab Wahid (2011) Euphorbia neriifolia Linn: A Phytopharmacological Review IRJP 2(5): 41-48.

8. Kirtikar KR, Basu B D (1994) Indian Medicinal Plants 2(30) Deharadun 2202.

9. Shastry JLN, Dravyaguna Vijnana (2005) Vol 2, Chukhambha Orientaliya, Varanasi, India (2 ${ }^{\text {nd }}$ edn) pp. 924.

10. Bigoniya P (2012) Euphorbia latex: a magic potion or poison. In: Gupta VK, editor. Traditional and folk herbal medicine: recent researches, Vol I. New Delhi, India Daya Publishing House, India.

11. Controller of Publications, Ministry of Health and Family Welfare, Department of Indian Systems of Medicine and Homoeopathy, Government of India. The ayurvedic pharmacopoeia of India. Part-I ( $1^{\text {st }}$ edn), vol. I. National Institute of Science Communication (CSIR), New Delhi, India.

12. Chinmayi Upadhyaya, Sathish S (2017) A Review on Euphorbia neriifolia Plant. Int J Pharma and Chem Res 3(2): 149-154.

13. Shah JJ, Jani PM (1963) Shoot apex of Euphorbia neriifolia L. Proceeding Nation Instit Sci India 30B(2): 80-91.

14. Sharma V, Pracheta J (2013) Microscopic studies and preliminary pharmacognostical evaluation of Euphorbia neriifolia L. leaves. Indian J Nat Prod Res 4(4): 348-357.

15. Anonymous (2003) The wealth of India, a dictionary of Indian raw materials and industrial products (Raw materials), Vol. III (D-E). New Delhi: Central Institute of Medicinal and Aromatic Plants pp. 226-228.

16. Ved DK, Sureshchandra ST, Barve V, Srinivas V, Sangeetha S, et al. (2016) Plant Details for a Euphorbia neriifolia L. Bengaluru: FRLHT's ENVIS Centre on Medicinal Plants.

17. Anonymous (2003) The wealth of India, a dictionary of Indian raw materials and industrial products (Raw materials), Vol. III (D-E). New Delhi: Central Institute of Medicinal and Aromatic Plants pp. 226-228.

18. Ilyas M, Mehtab Parveen, Kunwar Mohmmad Yusuf Amin (1998) Neriifolione, a triterpene form Euphorbia nerrifolia. Phytochemistry 489(3): 561-563.

19. Anjaneyulu V, Row RL (1965) The crystalline principles of Euphorbiaceae. $\mathrm{N}$. The triterpenes from the stem and leaves of Euphorbia neriifolia Linn. Current Sci 34: 608-609.

20. Mizno MZ, Tanaka T, Iinuma Mu, Xu GY, Huang Q (1989) Phytochem 28: 553.

21. Chatterjee A, Saha SK, Mukhopadhyay S (1978) Lewis acid-catalysed

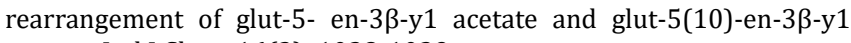
acetate. Ind J Chem 16(3): 1038-1039.

22. The Wealth of India: Raw Materials. Vol X, New Delhi: Council of Science and Industrial Research (CSIR) Publications, 1976: 588-590. 
23. Kapoor LD (1990) CRC Handbook of Ayurvedic plants. CSIR, USA, pp: 183.

24. Yen GC, Chen HY (1995) Antioxidant activity of various tea extracts in relation their antimutagenicity. J Agric Food Chem 43: 27-32.

25. Yadav RP, Patel AK, Jagannadham MV, Neriifolin S (2012) A dimeric serine protease from Euphorbia neriifolia Linn: purification and biochemical characterization. Food Chem 132(3): 1296-1304.

26. Yadav RP, Patel AK, Jagannadham MV (2011) Purification and biochemical characterization of a chymotrypsin-like serine protease from Euphorbia neriifolia Linn. Process Chem 2011; 46(8): 1654-1662.

27. Mallavadhani UV, Satyanarayana KVS, Mahapatra A, Sudhakar AVS (2004) A new tetracyclic triterpene from the latex of Euphorbia neriifolia. Nat Prod Res 18(1): 33-37.

28. Roa DN, Row LR (1965) The crystalline principles of Euphorbiaceae. Part III. Curr Sci 14: 432.

29. Seshagirirao K, Prasad MN (1995) Purification and partial characterization of a lectin from Euphorbia neriifolia. Biochem Mol Biol Int 35(6): 1199-1204.

30. Mallavadhani UV, Satyanarayana KVS, Mahapatra A, Sudhakar AVS, Narasimhan K, et al. (2006) Development of diagnostic microscopic and chemical markers of some Euphorbia latexes. J Integr Plant Biol 48(9): $1115-1121$.

31. Ilyas M, Parveen M, Kunwar Mohammad YA (1998) Neriifolione, a triterpene from Euphorbia neriifolia. Phytochem 48(3): 561-563.

32. Joshi A, Giri R, Pathak AK (2015) Pharmacognostical Evaluation and Preliminary Phytochemical Screening of Euphorbia neriifolia Linn. Leaves, Int J Pharm Phytochem Res 7(2): 219-223.

33. Kumara SM, Pokharen N, Dahal S, Anuradha M (2011) Phytochemical and antimicrobial studies of leaf extract of Euphorbia neriifolia. J Med Plant Res 5(24): 5785-5788.

34. Pracheta J, Sharma V, Paliwal R, Sharma S (2011) Preliminary phytochemical screening and in-vitro antioxidant potential of hydroethanolic extract of Euphorbia neriifolia L. Int J Pharm Tech Res 3(1): 124-132.

35. D Kalita, CN Saikia (2004) Chemical constituents and energy content of some latex bearing plants. Bioresource Technology 92: 219-227.

36. Nadkarni AK (1954) Indian Matreria Medica. Bombay: Popular Prakashan 1: 524 - 526.

37. Anonymous Raw Material, In: The Wealth of India, Vol. III (DE). CSIR Publication, New Delhi, India 1952, 226.

38. Pullaiah T (2002) Medicinal plants of India. Department of Botany. Sri Krishnsdevaraya University, Anantapur 1: 245-246.

39. Kirtikar KR, Basu BD (1996) Indian Medicinal Plants, Vol. II, Internationa Book Distributors, Dehradun 1581.

40. Chopra RN, Nayar SL, Chopra IC (1954) Glossary of Indian Medicinal Plants. CSIR, New Delhi, India 114.

41. Gaur K, Rana AC, Nema RK, Kori ML, Sharma CS (2009) The antiinflammatory and antialgestic activity of hydro-alcoholic leaves extract of Euphorbia neriifolia Linn. Asian J Pharm Clin Res 2(1): 26-29.

42. Burkill, Ivor H, Haniff M (1930) “Malay Village Medicine." The Gardens' Bulletin, Straits Settlements. 6(2): 167-282.

43. Veena Sharma, Pracheta Janmeda, Lokendra Singh (2011) A Review on Euphorbia neriifolia (Sehund), Spatula DD 1(2): 107-111
44. Rasik AM, Sukla A, Patnaik GK, Dhawan BN, Kulshreshta DK (1996) Wound healing activity of latex of Euphorbia neriifolia Linn. Ind J. Pharmacol 28(2): 107-09.

45. Kalpesh Gaur, Rana AC, Nema RK, Kori ML, Sharma CS (2009) Analgesic activity of hydroalcoholic leaves extract of Euphorbia neriifolia Linn; Asian Journal of Pharmaceutical and clinical Research 2(1): 26-28.

46. Bigonia P, Shukla Alok, Singh Chandra Shekhar (2010) Dermal irritation and sensitization study of Euphorbia neriifolia latex and its antiinflammatory efficacy. International Journal of Phytomedicine 2: 240254.

47. Veena Sharma, Pracheta (2013) Anti-carcinogenic potential of Euphorbia neriifolia leaves isolated flavonoid against N-Nitrosodiethylamineinduced renal carcinogenesis in mice. Indian Journal of Biochemestry and Biophysics 50(6): 521-528.

48. Veena Sharma, Pracheta Janmeda (2014) Protective Assessment of Euphorbia neriifolia and its Isolated Flavonoid Against N-nitrosodiethylamine-induced Hepatic Carcinogenesis in Male Mice: A Histopathological Analysis, Toxicol Int 21(1): 37-43.

49. Pracheta J, Veena Sharma, Ritu Paliwal, Sadhana Sharma (2011) In vitro free radical scavenging and anti-oxidant potential of ethanolic extract of Euphorbia neriifolia Linn. International Journal of pharmacy and pharmaceutical sciences 3(1): 238-242.

50. P Bigoniya, AC Rana (2009) Subacute Effect of Euphorbia neriifolia Linn. on Hematological, Biochemical and Antioxidant Enzyme Parameters of Rat. Academic Journal of Plant Sciences 2(4): 252-259.

51. Kalpesh Gaur, Rana AC, Cauhan LS, Sharma CS, Nema RK, et al. (2009) Investigation of Immunomodulatory potential of Euphorbia neriifolia Linn. Against Beta methasone Induced Immunosuppression. International Journal of Pharmacy and Phyto Research 1(1): 8-11.

52. Bigonia P, Rana AC (2010) Pharmacological screening of Euphorbia neriifolia leaf hydroalcoholic extracts. J App Pharma 1(2): 1-17.

53. Mansuri MI, Patel VM (2013) Evalution of anti-diabetic and antihyperlipidemic activity of Euphorbia neriifolia Linn in high fat diet streptozotocin induced type-2 diabetic model. International Journal for Pharmaceutical Research Scolars 2(1): 83-89.

54. Papiya Bigoniya, AC Rana (2005) Psychopharmacological profile of hydro-alcoholic extract of Euphorbia neriifolia leaves in mice and rats. Indian Journal of Experimental Biology 43(10): 859-862.

55. P Bigoniya, AC Rana (2010) Protective effect of Euphorbia neriifolia saponin fraction on CCl4-induced acute hepatotoxicity. African Journal of Biotechnology 9(42): 7148-7156.

56. Snuhi Sehund: Euphorbia neriifolia Uses, Side effects, Research.

57. Nadkarni KM, Nadkarni AK (2007) Indian Materia Medica. ( $3^{\text {rd }}$ edn) Vol. I. Bombay: Popular Prakashan.

58. GS Pandey, Bhavaprakasa Nighantu (1992) In: B Mishra (Eds.) Indian Materia Medica. Varanashi, PA: Chaukhambha Bharti Academy, India, pp. 76-77.

59. ICMR report (1991) Multicentric randomized controlled clinical trial of Kshaarasootra (Ayurvedic medicated thread) in the management of fistula-in-ano. Indian J of Medical Research (B) 94: 177-185.

60. Samar K Basak, Partho K Bakshi, Sabitabrata Basu, Soham Basak (2009) Keratouveitis caused by Euphorbia plant sap. Indian J of Ophthalmology 57(4): 311-313.

61. Modi's Medical Jurisprudence and Toxicology (2013) Lexis Nexis Butterworths 24: 148. 


$\begin{array}{ll}\text { BIOMEDICAL } & \begin{array}{l}\text { Assets of Publishing with us } \\ \text { RESEARCHES }\end{array} \\ \text { - Global archiving of articles }\end{array}$

